\title{
BERTRAND RUSSELL'S CHARACTERIZATION OF BENEVOLENT LOVE
}

\author{
Marvin KoHL
}

Philosophy / SUNY College at Fredonia

Fredonia, NY 14603, USA

of the most intriguing aspects of the writings of Bertrand Russell is his determination to somehow combine reverence for reason with a love of love. He is convinced that faith in reason is best coupled with faith in love. Just as the old proverb tells us that butter is best with bread, Russell maintains that love is best with reason. It is this recognition, operating as a structural element, that gives his "proto-theory" its wisdom and genius.

Russell writes that "ethical theories may be divided into two classes, according as they regard virtue as an end or a means" and that he agrees mainly, though not wholly, "with those who think the first business of ethics is to define the good, and that virtue is to be defined as action tending to produce the good" (HWP, p. 179). The fundamental principle of ethics should be the promotion of happiness. ${ }^{\mathrm{H}} \mathrm{He}$ defines the morally good life as the life inspired by love and guided by knowledge. The end is happiness, the means are love and

I "My Religious Reminiscences", The Basic Writings of Bertrand Russell, ed. Robert E. Egner and Lester E. Denonn (New York: Simon and Schuster, I96I), pp. 3I-2. Reprinted from The Rationalist Annual, I938, pp. 3-8. Alan Ryan (Bertrand Russell. Political Life [New York: Hill \& Wang, 1988], p. I45) suggests that, for Russell, "civilization' rather than happiness is the supreme goal...." What Ryan perhaps should have said is that, because Russell loved humankind, he was committed to its survival because the latter is typically a necessary condition for happiness. 
knowledge. ${ }^{2}$ Thus he does not maintain that love or benevolence "is the whole of virtue, the one and only moral virtue" 3 but rather that, if one has to select two regulating ideals, two means which would best produce a better world, one of them would have to be benevolent love. He assumes the moral enterprise, as well as the general quest for excellence, requires commitment to this higher good and, in What I Believe (pp. 19-34), describes some of its most important features.

This paper focuses on these features. It explains why this characterization has been relatively neglected, why it appears problematic, and why- despite its apparent limitations-Russell was convinced that the cultivation of benevolent love would add an excellence that society would not otherwise have.

Let us begin by distinguishing between Russell's notion of benevolent love and a related notion of caring love. What is common to both is that each involves a concern for the good, that is, the happiness and well-being of another person. It is not here necessary to decide, as Hume does, that the passion and conjoined desire are inseparable but not the same, where being inseparable means that "love is always followed by a desire of the happiness of the person beloved, and an aversion to his misery." 4 It is only necessary to understand that the kinds of love here being described are generally accompanied by such a desire. In other words, a desire for the happiness and an aversion to a beloved's misery is an almost necessary, but not a sufficient, condition for tokens of both benevolent and caring love, and a necessary

${ }^{2}$ What I Believe (New York: E. P. Dutton, 1925), p. 20, and Philosophy (New York: W. W. Norton, 1927), p. 235. Since this analysis focuses on Russell's characterization of love in What I Believe, all references to this book will be found in my text.

${ }^{3}$ For example, Frankena suggests that, for Russell, benevolent love is the whole of virtue, the one and only moral virtue, the "cardinal" virtue. It would be less misleading to say that, for Russell, love is the causally cardinal, but not the whole of virtue. See William K. Frankena, "Beneficence/Benevolence" in Beneficence, Philanthropy, and the Public Good, ed. Ellen Frankel Paul et al. (Oxford: Basil Blackwell for the Social Philosophy Center, Bowling Green State U., 1987), p. 6.

4 David Hume, $A$ Treatise of Human Nature, ed. L. A. Selby-Bigge (Oxford: Clarendon P., I896), Bk. Ir, pt. II, Sec. vi; pp. 367-8. but not sufficient condition for their respective types.

A fundamental difference between benevolent and caring love is that the former is typically limited to having concern for the well-being and happiness of others while the latter involves, by its very nature, $a$ commitment to help, if that help proves necessary. Formally, the difference is as follows: If $X$ benevolently loves $Y, X$ feels affection toward and must cherish and generally desire the welfare of $Y$. But if $X$ caringly loves $Y, X$ (in addition to the above) is committed to help $Y$ and largely because of this, $X$ will intervene in $Y^{\prime}$ 's life if that action is necessary to protect an important good or prevent a serious harm. ${ }^{5}$ For example, if Barbara caringly loves George and if, unbeknownst to George, his life is threatened by deadly force, then Barbara (given the usual caveats about the limits of reasonable action) is required to help George. Similarly, if George caringly loves Barbara, he does more than wish what is really good for her, he helps her if that help is necessary to protect an important good or prevent a serious harm.

In making this distinction I do not wish to impugn benevolence or the love of benevolence. What I wish to suggest is that they differ and that for many purposes benevolence is not sufficient. For reasons discussed later, we may not be able to extend caring love as far as we can extend benevolent love. But I think a case might be made to show that, since caring love is a source of the fullest satisfaction known to human beings, it ought to be, and indeed often is, considered the primary emotional good, albeit a complex one.

I have not aimed at writing a general paper on Russell's theory of love. A complete analysis might include an examination of Russell's discussion of sex, marriage, parenthood, and the extent to which-if $X$ does benevolently love $Y-Y$ can know this to be the case. It might investigate the arguments he advances against the rationality of longterm commitment. ${ }^{6}$ It might also wish to explore the connection

$s$ For a discussion of reasons which may warrant intervention in the life of a beloved, see my "Caring Love and Liberty: Some Questions", Free Inquiry, 12, no. 2 (r992): 49-5I, 54 .

${ }^{6}$ For a powerful debate concerning commitment and the value of devotion in marriage, see Bertrand Russell and John Cowper Powys, Is Modern Marriage a Failure? A Debate (Norfolk, England: Warren House P., 1983). Contrary to Russell, I have suggested that a rational function of monogamy is to prevent vicious sexual competition, to protect the weak and powerless from the strong and more sexually appealing 
between Russell's theory of happiness and his theory of love. Suffice it here to say that there is a connection; but that it is not one of identity. Russell seems to believe that happiness is an almost indispensable condition for the good life, that "a happy life is to a considerable extent the same as a good life...."7

Nor will I attempt to discuss the connection between Russell's theory of benevolent love and the role of the educator. However, I would like to suggest that there is a need to investigate the claim that, although affection is, in some sense, the essence of a good character, it cannot (or at least need not) be taught. In other words, Russell believes that love and knowledge are the two main requisites for right action, yet, in dealing with moral education, he says nothing about love and seems content to take sensitivity or sympathy as one of the four pillars for building an ideal character. "My reason", writes Russell, "has been that the right sort of love should be the natural fruit resulting from the proper treatment of the growing child, rather than something consciously aimed at throughout the various stages." I suspect that Russell's explanation is not as plausible as he would have us believe; that the capacity to love and more adequate conceptualizations of this and related capacities can be fostered in young children perhaps as early as three or four years of age. 9

I have been mentioning Russell's characterization and implicit theory of benevolent love. This would suggest that there are other notions of love, some of them vital for a full understanding of Russell's social philosophy. The first is the distinction between romantic

members of society, and that monogamous marriage and the notion of life-time commitment is, in large part, "designed" to prevent a breakdown of society into a Hobbesian war of every man against every other man. See my "The Functions of Monogamous Marriage," Russell, s (1985): 162-8.

7 Wladyslaw Tatarkiewicz, Analysis of Happiness (The Hague: Martinus Nijhoff, 1976), p. 338. For example, Russell writes that "the good life ... is a happy life. I do not mean that if you are good you will be happy; I mean that if you are happy you will be good" (New Hopes for a Changing World [New York: Simon and Schuster, I95I], p. Io).

${ }^{8}$ Education and the Good Life (New York: Albert \& Charles Boni, 1926), p. 187.

9 For studies that explore the capacity of younger children to understand reasonably sophisticated "philosophical" concepts, see Gareth B. Matthews, Philosophy and the Young Child and Dialogues with Children (Cambridge: Harvard U. P., 1980 and I 984 ,
respectively). and non-romantic love. "I believe myself", writes Russell, "that romantic love is the source of the most intense delights that life has to offer ... something of inestimable value, to be ignorant of which is a great misfortune to any human being."'o Irving Singer admits that "there is much wisdom in what Russell here claims." But he adds that "it nevertheless perpetrates an unwholesome dichotomy between romantic and married love [and] ... magnifies the difference between the two types of love, treating them as if they could have virtually no effect upon one another." ${ }^{\text {II }}$ Singer, I believe, correctly points out the need to explore the conceptual and causal connections between these types of love. Similarly, there is a distinction between impartial and non-impartial love. Kenneth Blackwell argues that impartial love, a love somewhat akin to Spinoza's intellectual love of God, is an important part of impersonal self-enlargement and plays a central role in Russell's philosophy. ${ }^{12}$ Blackwell's discussion adds immeasurably to our understanding of impartial love and impersonal self-enlargement. But he (and, for that matter, Russell) has little to say about its connection with benevolent love.

To illustrate the nature of this problem, let me cite one important example. Russell opens his autobiography with the following statement:

Three passions, simple but overwhelmingly strong, have governed my life: the longing for love, the search for knowledge, and unbearable pity for the suffering of mankind...

I have sought love, first, because it brings ecstasy-ecstasy so great that I would often have sacrificed all the rest of life for a few hours of this joy. I have sought it, next, because it relieves loneliness-that terrible loneliness in which one shivering consciousness looks over the rim of the world into the cold unfathomable lifeless abyss. I have sought it, finally, because in the union of love I have seen, in a mystic miniature, the prefiguring vision of the heaven that saints and poets have imagined. This is what I sought, and though it might seem too good for human life, this is what-at last-I have found. (Auto. I, "Prologue")

10 Marriage and Morals (New York: Horace Liveright, 1929), p. 74.

II Irving Singer, The Nature of Love, Vol. 3: The Modern World (Chicago and London: U. of Chicago P., 1987), p. 6.

${ }^{12}$ The Spinozistic Ethics of Bertrand Russell (London: Allen \& Unwin, 1985). 
This passage eloquently expresses an adoration of love. But it also illustrates a looseness or what may be called "poetic licence". Russell may be talking about one type of love (possibly the love central to impersonal self-enlargement), a combination of several, or a combination of the best of all types, an undifferentiated "ideal glob" of highly positive and emotion-charged affect. It also seems to represent a romantic idealization. Although I do not have sympathy with Andrew Brink's inclination towards the genetic and other fallacies, his analysis of this passage and his general claim that Russell had a "hunger for a perfect unaltering love"I3 are plausible ones. "It may seem wrong", writes Brink, "to question so fine a statement, but I do not think that Russell's requirement of repeated ecstasy in love is realistic. This spiritual elevation seems to ask too much of ordinary human relations" and is part of Russell's "search for the perfect love" (pp. 17-19). Whatever may be the nature and role of perfect love, its relation with other kinds of love, especially benevolent love, remain unclear.

\section{III}

Much has been written about Russell's social philosophy. His writings, especially about sex and marriage, have been widely discussed. Even his contribution to the parenthood and family literature has been recognized. Jeffrey Blustein suggests that Russell's philosophy of the family "foreshadows contemporary worries about the survival of the family as an institution" and that "twentieth-century philosophy of the family opens with Bertrand Russell."I4 But we are hard pressed to find critical studies, or even mention, of his analysis of benevolent love. Irving Singer briefly discusses the dichotomy between romantic and married love. Robert Brown's Analyzing Love refers to Russell's marriage with Alys but only uses it as an example of both being in and out of love. ${ }^{\mathrm{IS}}$ And Alan Soble's important study does not even men-

${ }^{13}$ Brink, Bertrand Russell: a Psychobiography of a Moralist (Atlantic Highlands, N.J. Humanities P. International, 1989), p. 95. See my review in Choice, Oct. 1989, p. 290 ${ }^{14}$ Jeffrey Blustein, Parents and Children: the Ethics of the Family (New York: Oxford U. P., I982), p. 30.

is Robert Brown, Analyzing Love (Cambridge: Cambridge U. P., I987), p. 82. tion Russell's work. ${ }^{16}$

Justus Buchler does mention Russell's description of the essential characteristics of benevolent love. He writes that he wishes that Russell, immune to the aura of Christianity and extraordinarily perceptive to nuances of conduct, could have translated systematically the ethical import and application of the concept of love and demonstrated its felicity in a better philosophical environment. Buchler claims that, unlike C. S. Peirce, Russell does not address the issue of loving one's neighbour. ${ }^{17} \mathrm{He}$ concludes that passage by saying that "Russell is too deeply agitated by the effects of traditional morality to give sufficient speculative attention to salvaging its ethical foundation." ${ }^{8}$ Buchler then proceeds to applaud Russell's discussion of love in Principles of Social Reconstruction, using the phrase "moral splendour", but expresses disappointment with the definition and presumably with the theory outlined in What I Believe. In other words, Buchler suggests that there is a shift in Russell's theory of love, that on his earlier view his definition would have been regarded as incomplete, and that the earlier position is preferable largely because it is more spiritual. It is not necessary to decide here whether Buchler's analysis is correct. What, I believe, is important is that (in a paper that probably strongly influenced the literature) Buchler dismisses the discussion in What I Believe as being unworthy of an earlier, more Spinozistic, Russell.

Some thinkers may have simply accepted Buchler's judgment. But others, because they were curious or perhaps incensed by Buchler's almost out-of-hand dismissal, may have read, perhaps reread, the passages in question. In fact, What I Believe has probably been widely read in its own right. Singer, for example, concludes his great work on the history of the idea of love with the following:

${ }^{16}$ Alan Soble, The Structure of Love (New Haven \& London: Yale U. P., 1990).

${ }^{17}$ Justus Buchler, "Russell and the Principles of Ethics", The Philosophy of Bertrand Russelh, ed. P. A. Schilpp (Evanston: Northwestern U., 1944), p. 532.

${ }^{18}$ Buchler is referring to Russell's discussion of religious love in Principles of Social Reconstruction (1916), pp. 212-23, 245. What he seems to overlook is Russell's distinction between religious and instinctual love (p. 213), one which roughly parallels the distinction (Believe, p. 34) between love in a perfect world and love in the actual world. 
Bertrand Russell said: "The good life is one inspired by love and guided by knowledge." What the world needs now is not only love but also greater knowledge about the nature of love, in all its complexity. (Nature of Love, 3: 440)

Why, then, the relative lack of discussion of the What I Believe passages? There are several explanations. Briefly and by way of speculation, let me suggest the following incomplete list: (I) the "secret gold mine" hypothesis would claim that the passages probably have been widely read, carefully "mined", intellectually absorbed, but have been seldom cited or discussed; (2) the "obscured by other more interesting or important claims" hypothesis would claim the focus on his theory of impartial love, his claims about sex and marriage, and his own sexual behaviour simply indicates scholarly preference; or (3) the "David Hume/Bishop Butler Rehashed" hypothesis would claim that Russell is reviving the eighteenth-century doctrine that benevolence leads to happiness without adding anything significantly new.

IV

Let us now turn our attention to the passages in question. Russell boldly claims that "the good life is one inspired by love and guided by knowledge" (Believe, p. 20). He does not purport to be proving that this is so. The reason is that "no argument is possible" concerning the ends of life. According to Russell, if we desire to achieve some end, knowledge (scientific knowledge and knowledge of particular facts) may show us the preferable means but it can never show us that the ends, in themselves, are desirable. The underlying argument is as follows: Knowledge can never show us that ends, in themselves, are desirable. Having a good life is an end in itself. Consequently, knowledge can never show us that having a good life is desirable. In other words, Russell was convinced that we have neither intuitions (a direct awareness) nor knowledge (a mediated awareness based upon sufficient evidence) that a given view of the good life is true. Notice Russell writes that the good life is inspired by love and guided by knowledge, not that the good life is caused, or produced, by love alone. Unlike popular love charlatans who believe that human beings are love incarnate or that love alone cures all our woes, Russell is content to say that affection is an almost necessary condition for the good life. Thus, when he adds that "neither love without knowledge, nor knowledge without love can produce a good life", he is not saying that these ingredients are necessary and sufficient conditions. He is only urging that they are generally necessary conditions.

Suppose, for instance, that your child is ill. "Love makes you wish to cure it, and science tells you how to do so" (Believe, p. 3I). But wishing to cure an illness and knowing how to do so are not the same as having the appropriate medicine, the actual power to do so. What this means is that love and science are not enough. We also need power, the ability to change the world in order to obtain what love and science enjoins us to do.

As to whether love or knowledge is more fundamental, he writes:

Although both love and knowledge are necessary, love is in a sense more fundamental, since it will lead intelligent people to seek knowledge, in order to find out how to benefit those whom they love. But if people are not intelligent, they will be content to believe what they have been told, and may do harm in spite of the most genuine benevolence. (Believe, p. 2I)

I quote this passage at length because it is central to understanding Russell's social and political philosophy. It is not sufficient to be loving, even endlessly loving. For those who are deeply and endlessly loving are often dangerously gullible. They tend to believe things without sufficient evidence. They want so very much for the world to be a better place-their love for the ideal and the perfect is so great - that they often refuse to recognize the realities of the present world. This refusal to recognize relevant aspects of reality (notice I did not say accept that reality) results in an ill-informed ethical idealism.

Perhaps Russell should have explicitly said that love is more fundamental when or because it will lead intelligent people - that is, people who possess relevant actual knowledge, are receptive to new knowledge, and effectively distinguish between what is the case and what they want to be the case-to seek the knowledge needed to understand and benefit those whom they love. In short, love is more fundamental only when it inspires intelligent people to act.

Russell then tells us that knowledge and love are both indefinitely extensible and, therefore, that however good a life may be, a better life can be imagined (Believe, p. 20). This is consistent with what I have 
elsewhere ${ }^{\text {I9 }}$ called "a process satisfaction utilitarian ethic", a theory in which the basic meaning of right consists not in static qualities but in relations to vital moving processes, in which the content of moral ideals changes and requires almost continuous pursuit. For Russell believes: ( $\mathrm{r}$ ) that the good life or happiness requires almost continuous activity; and (2) that, if knowledge and love are capable of being indefinitely extended, then it follows that however good a life may be, a better life can be imagined because we can always imagine a world in which there is more knowledge and more love.

But is love indefinitely extensible? That is to say, can we love almost endlessly? Of course, much turns upon what is meant by love. If it minimally means having a feeling of affection for and a rudimentary desire for another's welfare, like well-wishing, then it may well be indefinitely extensible. For there is a venerable tradition which holds that, because certain positive feelings are not quantitatively exhaustible, the feeling of affection when merely combined with wellwishing (or benevolent love) is, indeed, indefinitely extensible. In this sense of the term, a parent may tell his or her child that love is not like milk. Once we drink a quart of milk, it is gone. But benevolent love is not used up by extending it to many objects or to many children. For we can direct well-wishing and feelings of affection to any number of children, if not to any number of objects. And don't we often say such things as: "I wish all my children equally well" or that "There is no good reason for sibling rivalry since love is not exhausted by the number of children it is extended to"?

Why then, we may ask, is an intelligent child suspicious? I venture to suggest that, although an intelligent child may understand the virtues of benevolent love, he or she also understands that there is a difference between benevolent love, which because of its nature is indefinitely extensible, and caring love which because of its nature is not. An intelligent child understands that, since caring love often requires the combination of desire and action on behalf of the wellbeing and happiness of the beloved, it is often easily exhausted. The distinction seems to rest upon the difference between being capable of

19 "Russell and the Attainability of Happiness", International Studies in Philosophy, I6, no. 3 (I984): 14-24. having unlimited feelings qua mere feelings and having unlimited time and energy. Mere liking and well wishing may be unlimited, but time and energy are not.

Even if we limit our discussion to benevolent love, there are diffculties. For example, Russell admits that delight, in this world, is unavoidably selective (Believe, p. 28). Generally, we do not delight in the contemplation of what we perceive to be ugly or what we perceive to be evil. Nor do we typically love our enemies. Russell mentions fleas and bugs and lice. His suggestion is that by trying to see beauty in them we would be doing violence to our nature. But do we not do even greater violence to our nature - to say nothing about the nature of caring love-if we attempt to love a Hitler, a Stalin, or a Sadam Hussein? So why does Russell open this paragraph (Believe, p. 26) by saying that "In a perfect world, every sentient being would be to every other the object of the fullest love, compounded of delight, benevolence, and understanding inextricably blended"? Why does he then immediately add that "it does not follow that, in this actual world, we ought to attempt to have such feelings towards all the sentient beings whom we encounter"? Perhaps the answer is that in a perfect world every sentient being would be lovable and; therefore, easy to love. But we do not live in a perfect world. Nor does Russell seem to believe that we should act as if we do.

We have already observed that, given Russell's remarks in What $I$ Believe, ordinary human beings ought not to strive for the aforementioned perfect world. Of course, he may not have considered himself to be ordinary. But in this particular context he holds that man, in the actual world, seems to be limited to the general constraints of human nature.

Benevolence has its limits. For example, one cannot expect that a person's feelings towards a rival in marriage-and presumably towards any other rival — can be wholly benevolent. We are constrained, he suggests, by our animal nature and instinct, without which life becomes tame and uninteresting. And he concludes this aspect of the discussion by saying:

Instinct has its rights, and if we do violence to it beyond a point it takes vengeance in subtle ways. Therefore in aiming at a good life the limits of human possibility must be borne in mind. Here again, however, we are 
brought back to the necessity of knowledge. (Believe, p. 28)

The implicit argument is as follows: In aiming at the good life, human nature and possibility must be kept in mind. Given human nature, as it is currently known, it is not possible for most of us to be universally loving. Therefore in aiming at the good life, we ought not aim at being universally loving.

Russell does not attempt to provide a real definition of love. That is to say, he does not attempt to state necessary and sufficient conditions. Instead he metaphorically characterizes love, presumably only benevolent love, as an emotion which moves between the poles of pure delight in contemplation and pure benevolence (Believe, p. 22). If $X$ loves $Y$, then $X$ has an emotion which in some degree combines a contemplative appreciation of the object in question with feelings of benevolence.

What is innovative about Russell's conceptualization of love is that it helps make sense of talk about loving inanimate objects. Although Russell has problems unpacking the notion, he believes we can love and sensibly talk about (without shifting senses) loving parts of the environment, art objects, or causes which we hold in esteem. Thus he writes:

Where inanimate objects are concerned, delight alone enters in: we cannot feel benevolence towards a landscape or a sonata. This type of enjoyment is presumably the source of art. $\mathrm{I}_{\mathrm{t}}$ is stronger, as a rule, in very young children than in adults, who are apt to view objects in a utilitarian spirit. It plays a large part in our feelings towards human beings, some of whom have charm and some the reverse, when considered simply as objects of aesthetic contemplation. (Believe, pp. 22-3)

This passage is perplexing. On the face of it, it would seem that if we can love inanimate objects, and if this love is a form of benevolence, then we can feel benevolence towards a landscape or a sonata. Of course, much depends upon what is being packed into the notion of benevolence. For example, if sympathy (conceived of as an affinity for or relationship between persons or things wherein whatever affects one similarly affects the other) is a necessary condition, then it is possible to feel benevolence towards a landscape or a sonata. Although to say that one feels sympathy towards such objects does have an odd ring about it.

Similar linguistic or conceptual difficulties are encountered when we talk about having empathy. If we define empathy, broadly, as the capacity for participation or sharing in another's feeling, ideas, or essential being, then we can have empathy with inanimate objects. If, however, the notion of empathy is limited to "feeling with' another sentient being" or limited to "the capacity or act of participation in another's feelings", then it is obviously not possible to have this experience with inanimate objects.

However, suppose that Russell is not packing sympathy and empathy into the notion of love per se but only into one of its two poles. Remember he has told us that love, as an emotion, moves between two poles: on the one side, pure delight in contemplation; on the other, pure benevolence. Presumably, pure benevolence involves empathy, sympathy, and active concern about the welfare of the object in question. Presumably, pure delight is a form of ecstasy marked by intense liking. Notice that there is no linguistic or conceptual diffculty with our saying that we love (in the sense of intensely liking) inanimate objects. But being an $X$ is one thing and, except for things that are essentially pure (like the god of theism), being a pure $X$ is another. Hence benevolence is one thing, pure benevolence another.

As mentioned earlier, Russell does associate benevolence with wellwishing or the disposition to do good and promote the welfare of others. In fact, one may be tempted to argue that well-wishing is the central characteristic of, if not the necessary and sufficient condition for, benevolence. But there is a difficulty. It is true that strongly empathetic and sympathetic people are more likely to feel benevolent. But, given this central sense of benevolence and what it designates, empathy and sympathy do not appear to be necessary conditions. Each of these claims are empirical. The former is about the psychology of people; the latter about how the language is currently used.

However, all is not lost. If benevolence is limited to well wishing, to the desire for the welfare of the object in question, then it is possible to benevolently love inanimate as well as animate objects. For example, as "impure" benevolent lovers we often want to protect the physical existence of, as well as experience "closeness" with, an object. I have a copy of Van Gogh's Cottages in Saint Remy and Auvers in my study. To the extent that I "benevolently love" the print, I wish it well 
and want to protect it. And if I did not merely love my own print but the possibility of experiencing it, I probably would also desire that the original not be harmed or destroyed. In other words, to the extent I benevolently loved my print, I would generally delight in its contemplation and desire its welfare even though the notion of how this may be done seems to require a more complex explanation than an explanation of how one can desire the welfare of, say, a human being.

The foregoing considerations may not, I think, seriously reduce our confidence in Russell's analysis. But we have yet to discuss other plausible objections.

To tell us to love, and not more carefully explain the differences between the pure poles, is one difficulty. To minimally describe benevolence as "the desire for another person's welfare" (Believe, p. 23) and yet insist that he is speaking about an emotion, not a principle (p. 24 ), is another problem. It may be said that all that need be done is to distinguish between having the desire for another person or object's welfare and having a feeling of affection and a desire for the same end, and call the former "benevolence" and the latter "benevolent love". I have already remarked that this adds a needed element of clarity. But I do not think that conceptual clarity is sufficient. If the good life is to be inspired by some kind of supportive value, then why limit this ideal to benevolent love? After all, Russell himself does not seem to limit it to mere benevolence. It is true that a world in which people are benevolent is more likely to produce more good than a world in which people are not. But if it is true, as this tradition believes, that strongly benevolent people will produce more good than people with other motivations will, then why not commit to a stronger ideal? Why not say that the good life should be inspired, not merely by benevolent love, but by caring love? Why not (given the usual caveats about the need for self-love and having reasonable limits on altruistic behaviour) say that we ought to be committed to help others when this help is necessary to protect important goods or prevent serious harms? Why not say that those who best promote life have caring love and knowledge for their purpose?

Russell would have been extremely reluctant to move in this direc- tion. The question is, why not? He does not raise the usual libertarian objections, at least not in What I Believe. However, he does insist that love at its fullest is a combination of delight and well-wishing, and not delight and beneficence. Thus he writes:

Love at its fullest is an indissoluble combination of the two elements, delight and well-wishing.... Delight without well-wishing may be cruel; wellwishing without delight easily tends to become cold and a little superior. A person who wishes to be loved wishes to be the object of a love containing both elements, except in cases of extreme weakness, such as infancy and severe illness. In these cases benevolence may be all that is desired. Converse$\mathrm{ly}$, in cases of extreme strength admiration is more desired than benevolence; this is the state of mind of potentates and famous beauties. We only desire other people's good wishes in proportion as we feel ourselves in need of help or in danger of harm from them. [My emphasis.] At least, that would seem to be the biological logic of the situation, but it is not quite true to life. We desire affection in order to escape from the feeling of loneliness, in order to be, as we say, "understood." This is a matter of sympathy, not merely of benevolence; the person whose affection is satisfactory to us must not merely wish us well, but must know in what our happiness consists. [Again, my emphasis.] (Believe, pp. 24-6)

This passage is remarkable in that Russell seems to be ambivalent, torn between the desire to be self-reliant and the desire to escape from the feeling of loneliness he, here and elsewhere, repeatedly talks about. Notice also that he does not say "we only desire other people's help in proportion as we feel ourselves in need" but rather that "we only desire other people's good wishes in proportion as we feel ourselves in need." The emphasis is on good wishes, not on being helpful.

A major reason why Russell may be reluctant to move beyond benevolent love is that benevolent love is indefinitely extensible but caring love is not. The implicit argument is as follows: Whatever be the supportive value needed to save the world, it must be indefinitely extensible. Caring love is not indefinitely extensible. Therefore caring love cannot save the world.

This argument is similar to the conclusion Russell wants to draw from the story he tells about a secret society of physiologists who, upon discovering an elixir which would make people kind, refuse to administer it because they are not themselves kind. He concludes that "only kindliness can save the world, and even if we know how to 
produce kindliness we should not do so unless we were already kindly." ${ }^{20}$ Certainly Russell is correct in saying that there is a transition problem. Notice also that in this passage (which is quoted from a book published a year earlier) Russell is arguing that only kindliness (not benevolence) can save the world. I would not want to exaggerate the importance of what might be a shift in usage were it not for the fact that Russell frequently reminds us that it is not enough to go about overflowing with feelings of benevolence, and that benevolence "must lead to work that is somehow connected, however indirectly, with the creation of a better world." 21

But if Russell holds benevolent love to be the supportive moral ideal, and not kindliness or beneficence, it appears to be true that, even though benevolent love is indefinitely extensible, it cannot save the world. If there is a paradox, it is as follows. Benevolent love is indefinitely extensible but it cannot save the world; caring love is not indefinitely extensible, but it could save the world if it were.

In order to better understand the force of this objection, let us return to the "love at its fullest" passage. Russell claims that "the person whose affection is satisfactory to us must not merely wish us well, but must know in what our happiness consists." Is this true? Is it true that the person whose affection is satisfactory to us must only wish us well and know in what our happiness consists? Or is it true that the person whose affection is satisfactory must also be disposed to actively help us if that is what our happiness requires?

I am not suggesting that all love is reducible to caring love. Nor am I suggesting that it is rational, on an individual level, to require support when it is not needed. I am, however, suggesting that a person who wishes to be loved, first, generally wishes to be the object of caring love; and second, that if $X$ caringly loves $Y$, then in addition to feeling affection, cherishing, and desiring the well-being and happiness of $Y, X$ is committed to help $Y$ especially if that help proves necessary
to the welfare of $Y$.

I also have suggested that, although Russell elsewhere stresses the importance of beneficence and frequently reminds us that it is not

${ }^{20}$ Icarus, or the Future of Science (New York: Dutton, 1924), p. 62.

2I "A Philosophy for You in These Times", Reader's Digest, 39 (Oct. 1941): 6. enough to go about overflowing with feelings of benevolence and that benevolence must lead to work that is somehow connected with the creation of a better world, in What I Believe he neither distinguishes between benevolence and beneficence, nor suggests that benevolence is not enough.

This, I believe, is a mistake. For Russell's theory of love, in What I Believe, is a theory about ideals that should guide society. Ideals are neither facts nor certainties. They are, in large part, resolves to substantiate frail goods and to bring into existence or protect other cherished goods. Russell wrote that a society "cannot be radically reformed except by a radical reform of ideals." 22 This captures an important feature of his social and political philosophy, namely, that radical reform requires a radical reform of ideals.

It is possible that Russell believed he was advocating a radical reform of society. In fact, someone may plausibly maintain that, given the non-benevolent nature of society in our (as well as in Russell's) day, it is a radical reform of ideals to suggest that we feel benevolently at least toward non-evil and non-enemies. But even if this is true, benevolence is not enough. Well-wishing will not produce the society Russell wants. Actually doing good will. That is to say, benevolence will not produce the significantly better society, but beneficence will.

Of course, we may wish to quibble about the difference between significant and radical reform. I would grant that, in a non-benevolent society, positing an ideal of benevolence is significant reform. But it is not as radical a reform as positing beneficence or caring love as the supportive ideal.

Again, what may be at issue here is the nature of Bertrand Russell as a radical reformer. Russell was not a utopian. He did not believe we could achieve perfection once and for all. He did believe that we could always make the world into a better place. Strictly speaking, he never argued for a happy world but rather for a happier one. What this may come down to is the contention that Russell's utilitarianism is limited to producing a happier world and that a more benevolent world would be a happier one. I agree. But I think that Russell may have, at

${ }^{22}$ In collaboration with Dora Russell, The Prospects of Industrial Civilization (London: Allen \& Unwin, 1923), p. 26. 
least in What I Believe, aimed too low; that by explicitly aiming at

both benevolence and beneficence the ideal of the good life is better formulated, since it seems to take us much further on the path of a better world. It has been with this conclusion in mind that I have emphasized the problematic nature, perhaps only the incompleteness, of Russell's otherwise illuminating analysis. 